\title{
O INDIANISMO E O LENDÁRIO EM IRACEMA DE JOSÉ DE ALENCAR E MACUNAÍMA DE MÁRIO DE ANDRADE
}

\author{
INDIANISM AND LEGEND IN JOSÉ DE ALENCAR'S IRACEMA AND MÁRIO DE ANDRADE \\ MACUNAÍMA'S
}

(D https://orcid.org/0000-0003-0961-1695Carlos César de Oliveira ${ }^{\mathrm{A}}$

${ }^{\text {A}}$ Pontifícia Universidade Católica do Rio de Janeiro(PUC-Rio), Rio de Janeiro, RJ, Brasil

Recebido em: 12dez. 2021 | Aceito em:2 jan. 2022 Correspondência:CarlosOliveira (carlosoliveira.prof@gmail.com)

\begin{abstract}
Resumo
O estudo em questão foi realizado a partir do olhar e da relação deste professor-pesquisador com a Literatura, por meio do qual coteja aproximações e distanciamentos entre Iracema de José de Alencar e Macunaíma de Mário de Andrade (OLIVEIRA, 2004). Tomando o indianismo e o lendário com referências, este estudo vem reforçar o importante papel da literatura na formação de leitores críticos e reflexivos, compreendendo que por serem atravessadas por um viés ideológico, as literaturas têm o seu caráter político. Ancorei-me numa abordagem qualitativa, por meio de um levantamento bibliográfico e da (re)leitura das duas obras. Para a análise, inspirei-me na Literatura Comparada (SAMUEL, 2002) e em alguns elementos da análise do discurso (BAKTHIN, 1988), o que me propiciou fazer um entrelaçamento entre as literaturas e a educação. Trata-se, portanto, de uma escrita que é um convite à leitura, a compreender a pluralidade das literaturas e que reitera o importante papel da oralidade nas práticas educativas. Por fim, apresento algumas considerações e inquietações acerca do ensino de literaturas e da importância de reinventá-lo, aproximando-o da linguagem das/os estudantes e do cotidiano da escola. E assim concluo: "Tem mais não"!
\end{abstract}

Palavras-chave: Indianismo; Literatura Comparada;Romantismo; Modernismo; Leitura.

\section{Abstract}

The study in question was conducted from the look and the relationship of this teacherresearcher with Literature, through which he compares approximations and distancements between José de Alencar's Iracema and Mário de Andrade's Macunaíma (OLIVEIRA, 2004). Taking the Indianism and the legendary as references, this study reinforces the important role of literature in the formation of critical and reflective readers, understanding that because they are crossed by an ideological bias, literatures have their political character. I anchored myself in a qualitative approach, by means of a bibliographical survey and the (re)reading of the two works, and for the analysis I was inspired by Comparative Literature (SAMUEL, 2002) and in some elements of discourse analysis (BAKTHIN, 1988), which allowed me to make an interconnection between literature and education. It is, therefore, a writing that is an invitation to read, to understand the plurality of literatures, and that reiterates the important role of orality in educational practices. To conclude, I present some considerations and concerns about the teaching of literature and the importance of reinventing it, bringing it closer to the language of the students and the school's daily life. And so I conclude: "There is no more!

Keywords:Indianism; Comparative Literature; Romanticism; Modernism; Reading. 


\section{Primeiras andanças: um encontro com os autores e um exercício de autoria}

A temática do índio está presente na literatura desde o período colonial, e foi trabalhada por vários autores, entre eles, José de Alencar e Mário de Andrade, com os quais dialogo neste estudo. Por meio dele, retrato que tanto Alencar quanto Andrade, a partir de diferentes contextos e perspectivas, fez da literatura um instrumento que nos ajuda a compreender o panorama histórico-cultural brasileiro. Nesse sentido, o nacionalismo romântico, presente na obra alencarina, e o ideal de brasilidade marioandradiano, nos apresentam o Brasil como pano de fundo e, ao mesmo tempo, nos convidam a explorar os mitos e as lendas que compõem a cultura brasileira, tomando como referência o "indígena".

Com base nisso, afirmo que a literatura adquire um papel importantíssimo no âmbito da educação, pois, a partir de um olhar artístico e inventivo, o autor é capaz de fazer a sua leitura da realidade, (re)criando-a a partir de sua ótica. Por esse motivo, ao analisar uma obra literária é importante situá-la no tempo em que a mesma foi escrita, para, então, buscar compreender algumas de suas nuances: a linguagem empregada, o gênero trabalhado, o estilo, e, até mesmo, o público que se destinava no momento em que fora escrita. A respeito disso, procuro tecer algumas reflexões no decorrer deste texto.

Partindo dessa premissa, "O indianismo e o lendário em Iracema e Macunaíma" (OLIVEIRA, 2004), escrito à luz da Literatura Comparada, discute o índio em épocas e estilos diferentes, ou seja, no Romantismo e no Modernismo, sugerindo várias possibilidades de interpretação e análise. Na visão alencarina, é possível notar as marcas da colonização, da exploração do nativo por parte do colonizador, além de um "mundo selvagem" que ao se encontrar com a cultura do "homem branco" acaba perecendo diante dele, como é o caso de Iracema. A narrativa destaca a miscigenação entre brancos e índios, como um dos pilares da formação da sociedade brasileira. Se Moacir, fruto do amor de Iracema com Martin, significa "filho do sofrimento" (ALENCAR, 1997, p. 75), podemos inferir que os processos de miscigenação, ou de imposição de uma cultura (que se afirma mais forte) sobre outra, resultam em dor, perdas e sofrimento, a exemplo do que sugere Bosi (1992) em "Dialética da colonização".

Diferentemente de Alencar, através de Macunaíma ${ }^{i}$ Mário de Andrade dá ênfase à mitologia indígena e ao folclore brasileiro, apresentando um herói com características totalmente opostas à heroína romântica. Vale ressaltar que graças às suas características, alguns estudiosos consideram Macunaíma um "anti-herói”, um "herói sem nenhum caráter" (ANDRADE, 2001), no entanto, eu prefiro chamá-lo de um herói de múltiplas faces, tendo 
em vista que as nas suas andanças pelo Brasil ele incorpora as várias faces deste país plural. Enfim, como nos diz Samuel (2002, p. 15) "a literatura fala do mundo através de uma imagem do mundo", ou seja, "a literatura imagina," "produz imagens, manifestações sensíveis das ideias das coisas, visibilidade mental” (Idem, p. 13). Portanto, este texto é fruto desta "visibilidade mental", construída a partir de encontros com estes dois autores durante o trabalho final de graduação ${ }^{\text {ii }}$, que ouso revisitá-lo, retomar o nosso encontro, neste ano do centenário da Semana de Arte Moderna de 1922, que teve Mário de Andrade como um de seus protagonistas.

E qual o meu objetivo, com este texto? A partir de uma viagem pelos dois romances a leitura proporciona isso - investigar e analisaro indianismo e o lendário nas duas narrativas, cotejando aproximações entre os seus autores. Além disso, este estudo vislumbra destacar o papel da literatura no âmbito da educação, realçando a possibilidade de dialogar com outras áreas do conhecimento.

Metodologicamente, trata-se de um estudo qualitativo que teve como base a revisão bibliográfica. Nesse sentido, o estudo dialoga com autores como Bosi (1992; 2000), Moisés (1969), Santiago (2000), Samuel (2002), Gonçalves (2002), e, sobretudo, com Alencar (1997) e Mário de Andrade (2001). A pesquisa partiu de uma leitura minuciosa dos dois romances "Iracema" e "Macunaíma", seguindo-se de anotações e fichamentos, seleção de imagens, com vista no mapeamento dos mitos e lendas presentes nas duas obras. Quanto à análise, inspirando-me na Literatura Comparada (SAMUEL, 2002) e na análise do discurso (BAKHTIN, 1988), procurei explorar as mensagens, isto é, o discurso empregado por cada autor no que se refere às representações do "herói", ou seja, do indígena brasileiro.

Enquanto um exercício de pensamento, de ordenação e sistematização de ideias, considero que este (re)encontro com os autores se deu em um momento oportuno,talvez até com um tom laudatório aos modernistas que organizaram a Semana de Arte Moderna de 1922. Afinal, cá estou, cem anos depois, ensaiando uma escrita manifesto, organizada em três momentos: inicialmente, apresenta a temática do índio nas concepções romântico e modernista; em seguida, coteja aproximações e distanciamentos entre Iracema e Macunaíma e, por fim, apresenta algumas considerações e inquietações sobre o texto, ressaltando o papel da leitura e do ensino crítico-reflexivo, criativo, das literaturas. Convém dizer que apesar de muito leitores considerarem as duas obras complexas, de "leitura difícil", este estudo vem destacar a riqueza poética e linguística que elas têm, o que as tornam fascinantes. Enfim, é um convite a viajarmos e aprendermos juntos! 
Iniciemos esta viajem...

\section{O índio nas concepções romântico e modernista}

Na literatura brasileira, em vários momentos podemos encontrar a presença do índio, especialmente nas estéticas literárias da chamada Era Colonialiii (1500-1836), que precede o Romantismo (início da Era Nacional). Ora tratado pelo seu heroísmo, ora tratado como selvagem, desde a Carta de Pero Vaz de Caminha as narrativas retratam o olhar do branco colonizador sobre o nativo brasileiro, a quem se designou chamar de "índio". Em suas descrições, o nativo é quase sempre tratado como um selvagem, que graças o processo de aculturamento - de imposição da cultura do colonizador sobre o colonizado - é silenciado.

As vozes dos povos nativos são silenciadas, uma vez que são contadas a partir da ótica do colonizador, basta analisar as cartas, os tratados, as crônicas e alguns sermões escritos no período colonial. Vale lembrar que já no Quinhentismo nos deparamos com uma literatura de caráter documental, marcada pelo descritivismo, por relatose registros cartográficos, que nos servem para viajar pela época e, quiçá, para indagá-las: o que faz a cultura do colonizador ser superior à do colonizado? Qual a razão da apropriação, inclusive religiosa, da língua nativa? Por que as múltiplas culturas e dialetos nativos foram dizimados (BOSI, 1992)? "Evitar o bilinguismo significa evitar o pluralismo religioso e significa também impor o poder colonialista. $\mathrm{Na}$ álgebra do conquistador, a unidade é a única medida que conta", concluiu Santiago (2000, p. 14).

A presença do índio como "herói" surge com maior expressividade no Arcadismo (Neoclassicismo), a partir de poemas de Basílio da Gama (O Uraguai) e de Santa Rita Durão (Caramuru). É importante destacar que mesmo tratando o "índio" como herói,as duas obras também refletem as marcas do processo de aculturação, ou seja, quando a cultura do colonizador já está tão entranhada na vida dos nativos que os levam a se tornarem subservientes, a perderem a sua identidade. No poema o "Uraguai", por exemplo, Basílio da Gama retrata um heroísmo indígena que perece em detrimento dos valores do colonizador. Em “Caramuru”, Santa Rita Durão apresenta o índio como um ser que perde a sua autenticidade em virtude de valores religiosos e de sua ambição. A partir disso, levanto a âncora para seguir a viagem. Mas, antes de seguir deixo um convite à leitura, seja pelo simples prazer de ler, seja para olhar e indagar a história a partir da lupa da literatura.

E assim chegamos ao Romantismo. Em tempos de Brasil Império, os Romances de Folhetim passaram a contribuir para a formação de um novo público leitor. Ressalte-se que 
durante este período a temática do índio pode ser notada em poemas de Gonçalves de Magalhães e Gonçalves Dias, além da prosa de José de Alencar. Sobre este período, abro um parêntese para destacar, ainda, a ausência de mulheres escritoras, tanto nos Manuais de Literatura aqui estudados como na minha própria formação em literatura.Todavia, desde que este estudo foi realizado em 2004 (agora revisitado), pesquisas vêm sendo feitas nesse campo, problematizando não somente esta ausência, mas o fato de mulheres historicamente usarem pseudônimos masculinos frente a proibição/interdição de sua escrita.

Portanto, o indianismo romântico nasceu numa jovem "nação independente" (?) que precisava criar um passado histórico, mítico, lendário, capaz de identificá-la como nação, mas que também a distinguisse da Europa, sobretudo de Portugal. Constata-se, porém, que na Europa o nacionalismo dos autores românticos fora marcado pela valorização dos temas heróicos medievais. Mas, como no Brasil a história oficial considera como marco histórico o ano de 1500, com a chegada dos colonizadores portugueses, o nacionalismo brasileiro exaltou o índio: um índio idealizado, corajoso, puro, honrado e hospitaleiro.

Iracema acendeu o fogo da hospitalidade; e trouxe o que havia de provisões para satisfazer a fome e a sede: trouxe o resto da caça, a farinha d'água, os frutos silvestres, os favos de mel, o vinho de caju e ananás.

Depois a virgem entrou com a igaçaba, que na fonte próxima enchera de água fresca para lavar o rosto e as mãos do estrangeiro.

Quando o guerreiro terminou a refeição, o velho Pajé apagou o cachimbo e falou:

- Vieste?

- Vim: respondeu o desconhecido.

- Bem-vindo sejas. O estrangeiro é senhor na casa de Araquém.

(ALENCAR, 1997, p. 19)

O trecho em destaque relata o momento em que o guerrreiro branco Martim, a partir do seu encontro com Iracema, se insere na tribo dos Tabajaras. A figura do índio, ora representado por Iracema e por Araquém, é caracterizada pela sua docilidade e hospitalidade. É importante destacar que na prosa romântica o índio foi difundido a partir da chamada “trilogia alencarina": Ubirajara, Iracema e O Guarani. Partindo dessa perspectiva, o Romantismo brasileiro transformou-se em um projeto que objetiva a valorização dos elementos nacionais, destacando o índio como parte integrante desta história, porém numa condição de subalternizado, de "bom selvagem". A exemplo disso, destaco a relação entre Martim e Iracema (em Iracema), entre Ceci e Peri (em O Guarani), onde a posição ocupada pela mulher e pelo homem indígena é inferior à ocupada pela/o branca/o. 
Ao discutir a relação entre o Romantismo brasileiro e o europeu, Bosi (1992) afirma sobre uma "romantização das origens nacionais". Para este autor,

Lá, figuras e cenas medievais; cá, o mundo indígena tal e qual o surpreenderam os descobridores. Cá e lá, uma operação de retorno, um esforço para bem cumprir o voto micheletiano de ressuscitar o passado, alvo confesso da historiografia romântica.

[...] No caso brasileiro, um dosveios centrais do nosso romantismo alencarino, também mostrou-se receoso de qualquer tipo de mudança social, parecendo esgotar os seus sentimentos de rebelião ao jugo colonial nas comoções políticas da Independência (BOSI, 1992, p. 176).

Isso significa dizer que as lutas travadas entre colonizadores e indígenas durante o período de colonização, a exploração, o aculturamento, submergem diante desse retorno ao passado. Em outras palavras, a "dialética da colonização" (BOSI, 1992), seus desafios, seus dilemas, as atrocidades cometidas aos povos indígenas, acaba ficando em segundo plano, seja como cenário ou como coadjuvante na/da ação e, por vezes, nem aparecendo. Para Bosi,

O índio de Alencar entra em íntima comunhão com o colonizador. Peri é, literal e voluntariamente, escravo de Ceci, a quem venera como sua Iara, "senhora", e vassalo fidelíssimo de D. Antônio. No desfecho do romance, em face da catástrofe iminente, o fidalgo batiza o indígena, dando-lhe o seu próprio nome, condição que julga necessária para conceder a um selvagem a honra de salvar a filha da morte (BOSI, 1992, p. 177, grifos do autor).

Diante disso, a literatura abre caminhos para pensarmos que nos processos de colonização, visto que se fundamentam em interesses econômicos, a identidade cultural do povo nativo é desrespeitada e, muitas vezes, apagada, esquecida, conforme sugere o romance: “A jandaia pousada no olho da palmeira repetia tristemente: - Iracema!” (ALENCAR, 1997, p. 80). Porém, com passar do tempo, “A jandaia cantava no olho do coqueiro; mas não repetia já o mavioso nome de Iracema. Tudo passa sobre a terra" (Idem, p. 82).

Pensando nisso, Bosi (1992, p. 178-179) assevera que "Nas histórias de Peri e de Iracema a entrega do índio ao branco é incondicional, faz-se de corpo e alma, implicando sacrifício e abandono da sua pertença à tribo de origem. Uma partida sem retorno". No caso de Iracema, a heroína perece, porém do seu amor com Martim nasceu Moacir, que representa a miscigenação cultural. Mas destaco que a miscigenação também resulta em perdas, especialmente quando existe uma cultura considerada superior (poder) em relação à outra.

Sob o prisma da miscigenação cultural, Alencar apresenta elementos que me levam a refletir sobre a imposição da cultura européia e as marcas do colonialismo nas relações sociais, culturais, religiosas, ou seja, nas crenças, hábitos, costumes e, principalmente, na fala. 
Marcas presentes até os dias atuais, que foram alvo de críticas por algumas correntes literárias, a exemplo dos modernistas, conforme destacarei mais adiante.

Ainda em relação ao indianismo alencarino, Gonçalves (2002, p. 34) afirma que “Todos os que estão do lado dos portugueses são pintados com as cores do bem, da nobreza. Sobrevivem os que são criados à imagem e semelhança do ocidente". Um exemplo disso é Peri, que para permanecer vivo - fidalgo - precisou ser batizado, abrindo mão de suas raízes em pela sua relação de vassalo. Assim, tanto Iracema como Peri foram influenciados, porém acabou prevalecendo a lei do mais forte: o colonizador.

E quanto a Moacir? Fruto da relação entre Iracema e Martin, o significado do seu nome "filho do sofrimento" sugere que a miscigenação traz sofrimento, dores, perdas, especialmente quando há um desnível social, econômico e cultural.

Graças ao seu descritivismo, a sua riqueza estética e linguagem, Iracema é considerado um poema em prosa que retrata com heroísmo as lutas indígenas, revestido por um sentimentalismo exacerbado - “a virgem dos lábios de mel” tem uma beleza incomparável. Mas esta também não foi a reação dos colonizadores ao chegar ao Brasil? Se a virgem seduziu Martim, remotando-me ao período colonial quero lembrar o encanto dos portugueses seduzidos pelas belezas e riquezas das terras brasileiras. E assim inicia a sua exploração colonial!

Segundo Gonçalves (2002, p. 30) "Iracema representa a América pronta para ser explorada e submetida aos caprichos dos portugueses". Partindo desse pressuposto, pode-se inferir que a dedicação de Iracema (anagrama de América) ao seu companheiro é reflexo dessa submissão, pois a mesma vive para amá-lo e, por ele, abandonou a religião, a família, os costumes da tribo, traindo, inclusive, “os segredos da jurema” (ALENCAR, 1997). Por outro lado, percebe-se que apesar de ser influenciado pelos hábitos e costumes indígenas, o colonizador não perde a sua identidade, principalmente porque domina a língua dos nativos. Diante disso, apesar da crítica social não ser uma característica dos romances românticos, subjetivamente o romance aponta para três instrumentos de poder: a economia, a religião e a língua. A conjunção destes três fatores pode resultar em invasão, apropriação, exploração e dominação, não necessariamente nesta ordem.

Conforme já destacadoem “- Vieste! - Vim: respondeu o desconhecido. - Bem-vindo sejas. O estrangeiro é senhor na casa de Araquém",foi através da linguagem que Martim se aproximou de Iracema e se instalou na cabana de Araquém, estabelecendo diálogo com o pajé. Dessa forma, o "guerreiro branco" na tribo dos Tabajaras representa a invasão a partir do 
domínio da língua, cuja imposição contribuirá para introjetar os hábitos, crenças e costumes do colonizador na cultura da tribo. Assim, aos poucos a língua do colonizador é introduzida e vai se tornando a "língua oficial", implicando na comunicação e, por conseguinte, refletindo as desigualdades sociais. Ao tratar da desigualdade, Aranha e Martins (1993, p. 224) afirmam:

No discurso sobe a desigualdade, Rousseau cria a hipótese dos homens em estado de natureza, vivendo sadios, bons e felizes enquanto cuidam da própria sobrevivência, até o momento em que é criada a propriedade e uns passam a trabalhar para os outros, gerando escravidão e miséria.

Com base neste enunciado, convém destacar a influência de Rousseau no indianismo alencarino, principalmente em Iracema. No romance, o nativo vive em plena harmonia com a natureza. As personagens, por sua vez, são comparadas aos elementos da natureza que os cercam. Senão vejamos: Iracema "virgem dos lábios de mel, cabelos mais negros que a asa da graúna, e mais longos que o talhe da palmeira" (ALENCAR, 1997, p. 16). Além disso, o nativo tem os animais como amigos: "a graciosa ará, sua companheira e amiga, brinca junto dela. Às vezes, sobe aos ramos da árvore e de lá chama pelo nome” (Idem, p. 17). Como se pode notar, ambos viviam em plena harmonia com a natureza, até que chegou o colonizador/explorador. Então, a lógica começa a mudar.

A partir do momento que Iracema conhece Martim - o guerreiro branco - há uma mudança no seu comportamento. O sentimentalismo típico dos romances românticos aflora. Um sentimento que levou Iracema a quebrar "a flecha da paz", esquecendo-se das suas responsabilidades como guerreira.

A mão rápida que ferira, estancou mais rápida e compassiva o sangue que gotejava. Depois Iracema quebrou a flecha homicida: deu a haste ao desconhecido, guardando consigo a ponta farpada.

O guerreiro falou:

- Quebras comigo a flecha da paz?

- Quem te ensinou, guerreiro branco, a linguagem de meus irmãos? Donde vieste a estas matas, que nunca viram outro guerreiro como tu?

- Venho de bem longe, filha das florestas. Venho das terras que teus irmãos já possuíram, e hoje têm os meus (Ibidem, p. 17-18, grifos meus).

Por ter o domínio da língua dos indígenas, Martim se aproxima de Iracema e estabelece a comunicação com a mesma. Sua fala expressa também esta ideia de posse, ao afirmar sobre as "terras que teus irmãos já possuíram", ou seja, que outros povos indígenas já possuíram, mas que os colonizadores se apossaram. Com isso, retomamos o pensamento de que a propriedade resulta em desigualdade, em exploração, em miséria. 
Seguindo as minhas andanças, dou adeus ao Romantismo em busca de outro herói indígena. Chego ao século XX impactado com a Semana de Arte Moderna de 1922, marco do primeiro momento modernista (1922-1930). É neste contexto que encontro com Mário de Andrade, o seu entusiasmo com o Brasil, num movimento de ruptura em defesa da cultura brasileira. Conhecedor do Brasil, ele escreveu Macunaíma. Trata-se de uma obra que rompe com a tradição romântica da idealização do índio, visto que ele perde a aura da ingenuidade e marcado pelo "jeitinho brasileiro". Abrasileirado, Macunaíma traz outra perspectiva de herói - um herói corrompido ou um anti-herói - que saí do Amazonas para São Paulo à procura do muiraquitã roubado. Além disso, destaca outras crenças, conforme destaco a seguir:

Figura 1 - Dá água de chocalho que a criança começa a falar
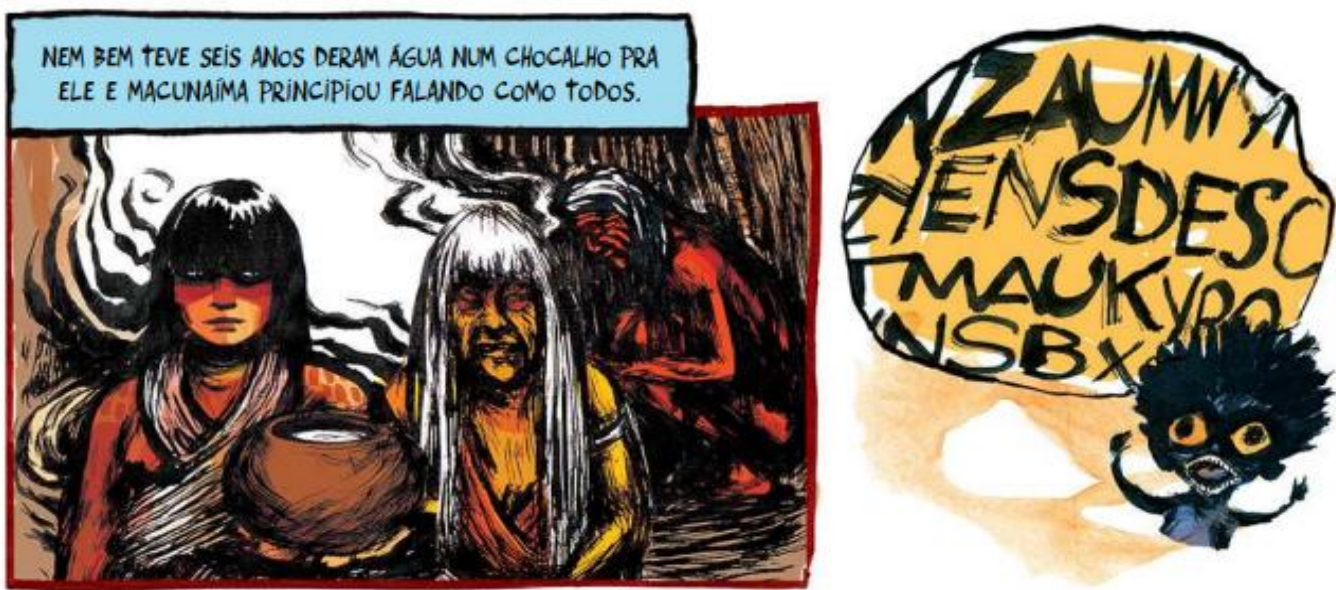

Fonte: Angelo Abu e Dan X, 2016, p.10.

A figura em destaque ressalta que ao nascer Macunaíma demora a falar, para isso lhe dão "água de chocalho". Uma expressão corriqueira na linguagem popular, especialmente quando a pessoa fala muito. "Parece até que bebeu água de chocalho"! Nas minhas andanças já ouvi esta expressão. Além disso, Macunaíma é envolvido por um universo mágico: ele cresce, vira criança, se torna príncipe, volta ao normal, entre as tantas aventuras por que passa.

A respeito do romance marioandradiano, Moisés (2001, p. 61) afirma que "O índio experimenta todas as reações humanas - inclusive as do medo, ódio, desespero, inveja, raiva foge dos perigos, chora e chega até a morrer, e a sua conversão na Ursa Maior representa o cúmulo abandono da sua condição heróica”. Senão vejamos, filho da tribo Tapanhumas, Macunaíma é o herói que nasce no "mato-virgem", mas em busca do muiraquitã roubado que ganhou de $\mathrm{Ci}$, deixa o seu povo e vai para “a cidade grande”. Lá, ele se depara com o 
desenvolvimento, a luta por sobrevivência, a mudança cultural, a exploração: como lidar com tudo isso? São tantos Macunaímas... Enfim, mas isso é outra questão. Agora, me deterei às lendas, aos mitos e crendices populares, a partir da narrativa.

Diante disso, pode-se dizer que na perspectiva modernista o índio é trabalhado a partir de seus aspectos míticos e lendários, de suas crendices, numa tentativa de valorizar os elementos da cultura brasileira, sobretudo do folclore. Ao trazer para a narrativa o Anhangá, o Mapinguari, a Mula-sem-cabeça, o Boitatá, o Saci-pererê, o Negrinho do Pastoreio, a Boiúna, o Curupira, a Mãe d'água e o próprio Macunaíma, Mário de Andrade explora as representações fantásticas recorrentes no imaginário popular brasileiro. Sobre esse assunto, ao escrever a folha de rosto de "Macunaíma em quadrinhos", Sílvia Oberg afirmou:

Prevendo o espanto que seu herói causaria, Mário diz que o que escreveu "não é um romance, nem um poema, nem uma epopéia." (...) "Diria antes, que é um coquetel. Um sacolejado de quanta coisa há por aí." E terminou por chamar o livro de 'rapsódia'. E é mesmo! Como as rapsódias musicais, compostas por uma variedade de cantos populares, Macunaíma é construído em uma espécie de colagem feita com mitos, folclore, histórias de origens variadas, superstições, provérbios, frases feitas, neologismos, palavras em tupi e anedotas que sintetizam o caráter de nosso povo e nossa cultura. Nos moldes antropofágicos, o autor mastiga e mistura as mais variadas referências culturais para refletir sobre a realidade brasileira (2016, folha de rosto, grifos da autora).

Escrito em apenas uma semana, graças à sua linguagem e riqueza de detalhes, essa mistura proposta por Mário de Andrade causou impactos na sociedade brasileira da época. A afirmação de que a obra não se tratava de um romance, um poema ou uma epopéia pode ser considerada uma ruptura - característica da "geração de 22" - com os gêneros textuais até então explorados pela literatura brasileira ou pura antropofagia. Mas afinal, em qual gênero se enquadraria a obra? Ela é uma mistura, uma "rapsódia", visto que reúne vários elementos da cultura brasileira: mitos, lendas, costumes, expressões linguísticas. Como bem lembrou Oberg (2016), a narrativa marioandradiana em Macunaíma é composta de "histórias de origens variadas", como as histórias ouvidas por Mário nas suas viagens e anotadas no seu caderno. Seria Mário um etnógrafo? Talvez esta seja uma questão que possibilite outras andanças por parte deste pesquisador interessado e curioso. Confesso que muitas delas já ouvi. E algumas até me causavam medo. Ah! curupira danado, que me metia medo ao andar na mata sozinho. De noite, o medo era da mula-sem-cabeça, especialmente quando a Boiúna Luna não aparecia. Vixe! Tinha medo de noite e de dia. 
Etnógrafo ou não, a partir de Macunaíma o autor coloca o leitor em contato com as superstições (Ver fig. 1), crendices populares, com danças típicas, palavras em tupi e anedotas representativas da cultura brasileira.

Figura 2 - O que é que Brasil tem?

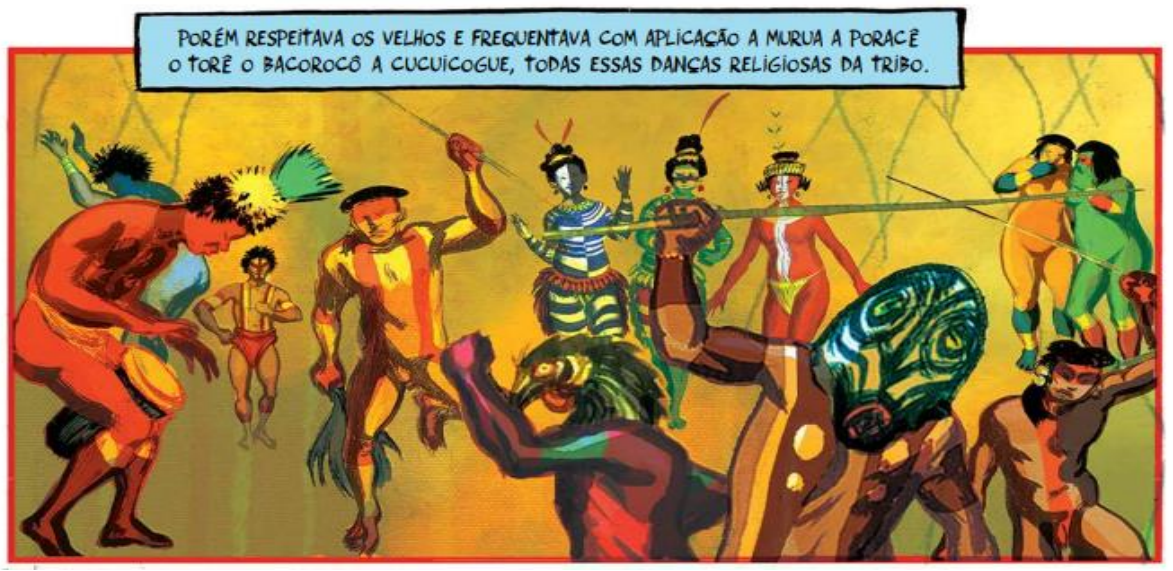

Fonte: Angelo Abu e Dan X, 2016, p. 10.

A partir dessa figura, nota-se que diferentemente de Alencar, Mário de Andrade retrata um herói humanizado, que passou a viver os medos e correr os riscos da vida moderna, entre sair da tribo e viver na cidade grande. De que forma essa mudança o afeta psicologicamente? Haveria um conflito de identidade em função da mudança? Pensando por esta ótica, pode-se dizer que o Brasil é uma representação macunaímica? Talvez. Lhes convido a pensar.

Sobre a "Geração de 1922", da qual Mário de Andrade fez parte, a literatura é marcada pela irreverência, pelo uso de paródias, a valorização da fala popular e uma prosa próxima ao povo, conforme destaquei acima. Nesse sentido, a primeira corrente modernista nos instiga a pensar a "tradição". Às vezes, o conceito de "tradicional" ou "tradição" é visto de forma pejorativa, tendo em vista a tradição construída a partir do colonizador, como sugerem os romances indianistas de Alencar. Porém, Macunaíma (Ver fig. 2) nos sugere olhar para a tradição a partir do colonizado, isto é, dos povos nativos, dos seus ritos, danças, mitos e lendas indígenas e causos populares, características que representam o caráter nacional. Pensemos nisso...

E assim, findamos este primeiro momento da viagem, ou talvez deste relato de viagem que fiz a partir da leitura das duas obras, situando-as dentro de um contexto: ou seja, do Romantismo e da primeira fase Modernista. Encerro, porém, pensando no processo criativo da escrita, seja pela riqueza de detalhes, algo recorrente no indianismo alencarino, seja pela 
riqueza de fatos e de acontecimentos, presente na rapsódia macunaímica. A escrita, neste caso, é compreendida como um "processo criativo", resultado das múltiplas vozes que a tecem, e que agora se unem à sua voz, por meio da leitura.

\section{Aproximações e distanciamentos entre Iracema e Macunaíma}

Em que aspectos as duas obras se aproximam? E em que se distanciam? As andanças por Iracema e Macunaíma foram sugerindo pistas, caminhos, sobretudo quando se estabelece o diálogo com outros autores. Algumas explorarei neste texto, outras ficarão para outro exercício de escrita. Neste segundo momento do texto, parto da premissa que "O encontro do leitor com a palavra alheia" como sugerem Ramos e Chapper (2009) possibilita com que ele pense, reflita acerca dos ditos e não ditos no texto (BAKHTIN, 1988). O que há por traz das palavras?

Assim, à luz da Literatura Comparada, busquei analisar as aproximações e distanciamentos entre Iracema e Macunaíma, trazendo para discussão a questão do estilo (literário), do gênero textual, a temática do índio na Literatura Brasileira, os seus mitos e lendas. Mas, antes de adentrar na discussão, quero destacar que o meu gosto por Macunaíma, bem como por Mário de Andrade, surgiu ao final do ensino médio, após as inúmeras provocações feitas pela professora ${ }^{\mathrm{iv}}$ de Literatura. Com base nisso,

Acreditamos que é a interrogação, e não a convicção sobre as práticas de leituras e suas perspectivas de trabalho no cotidiano da sala de aula, que nos possibilita discutir o fluxo das práticas discursivo-simbólicas, na tentativa de estreitar o fosso ainda existente entre leitor/texto no cenário escolar (RAMOS; SCHAPPER, 2009, p. $6)$.

Nesse sentido, quero reforçar o importante papel das literaturas na formação do leitor e, por conseguinte, no exercício da autoria, conforme destaquei recentemente em um ensaio sobre A importância do "ato" de ler em Paulo Freire e Bakhtin (OLIVEIRA, 2021). Pois bem, foi a partir das leituras que fui me indagando sobre os elementos comparativos entre os dois textos. Contextualizando esta busca, ressalto que

A literatura comparada consiste em analisar as influências ocorridas entre duas literaturas (somente), no que se refere aos seguintes problemas: a) gêneros e estilos (genealogia); b) temas, tipos e lendas ou mitos (tematologia); c) ideias e sentimentos (mentalidades); d) sucessos e influências (doxologia, que na teologia patrística era a exaltação e o elogio de Deus, dóxa era a fama, a repercussão, o sucesso, a opinião) tratam da recepção, da repercussão; e) fontes (cronologia); f) intermediários (mesologia: de méson, entre meios, entre dois pólos) (VAN TIEGHEN, 1931 apud SAMUEL, 2002, p. 101-102, grifos do autor). 
A respeito desta influência, o primeiro momento deste texto já trouxe alguns elementos comparativos sobre a genealogia, a cronologia e a tematologia das duas obras. Contudo, neste momento, voltarei a explorá-los, especialmente no que se refere às "trilhas do mítico-lendário" (OLIVEIRA, 2004). Para princípio de conversa, reitero que as duas narrativas heróicas - Iracema e Macunaíma - estão situadas em contextos históricos e estilos literários diferentes. É importante destacar que os estilos (correntes ou períodos) literários vão se alternando de acordo com as mudanças que acontecem na sociedade: influenciando e sendo influenciado por elas. Não podemos esquecer aqui o "poder da linguagem" e o seu "caráter ideológico", conforme sugeriu Bakhtin (1988). Com base nisso, conclui-se que as literaturas apesar da defesa que são arte e/ou entretenimento, e não deixam de ser - elas são atravessadas por questões ideológicas, o que leva este estudo a concluir sobre o seu caráter político.

Quanto ao contexto histórico, Iracema foi escrito em meados do século XIX, mais precisamente em 1965, enquanto Macunaíma foi escrito no início do século XX, em 1927, conforme sugere Jason Tércio (2019), ou seja, cinco anos após a semana de Arte Moderna. No primeiro, o Império; no segundo, a República. Em um, o contexto em que a obra foi escrita é o Brasil recém-independente de Portugal, marcado por "revoltas", tendo como ambientação a cidade do Rio de Janeiro, onde se formava um novo público leitor a partir dos Romances de Folhetim. No outro, um período entre-guerras (primeira e segunda guerra mundiais) e a República do Café com Leite. Também é possível notar uma mudança de cenário, visto que a Semana de Arte Moderna foi realizada na cidade de São Paulo. Ressaltese que nesse contexto já há um público leitor formado. Com muita irreverência, foram publicados os Manifestos Pau-Brasil e Antropófago (Oswald de Andrade) e a Revista Klaxon, que vão muito além dos folhetins românticos. Por meio dos versos que se seguem, Manuel Bandeira expressa que, naquele contexto da década de 1920, os modernistas estão em busca uma estética literária capaz de contemplar os falares brasileiros, visto que até então a escrita literária não os contemplava.

Estou farto do lirismo comedido

Do lirismo bem comportado

Do lirismo funcionário público com livro de ponto expediente protocolo e manifestações de apreço ao Sr. Diretor.

Estou farto do lirismo que pára e vai averiguar no dicionário o cunho vernáculo de um vocábulo.

Abaixo os puristas 
Todas as palavras sobretudo os barbarismos universais

Todas as construções sobretudo as sintaxes de exceção

Todos os ritmos sobretudo os inumeráveis (BANDEIRA, 2017, s.p.).

A linguagem indignada e a reação às estéticas anteriores, sobretudo ao Parnasianismo - que prega a forma em detrimento do conteúdo, a métrica perfeita - chegam até mim como um convite a pensarmos neste centenário da Semana de Arte Moderna: Do que estamos fartos? Qual será o nosso ato de rebeldia? Reinventá-los é preciso.

Acredito, portanto, que esta escrita seja um ato de rebeldia, especialmente com relação aos "puristas literários" que, em geral, criticam esta aproximação entre a literatura e o real: visto que ela também "reflete e refrata"v a realidade (BAKHTIN, 1988). Agora, voltando-me para a estrutura da narrativa cumpre dizer que o romance alencarino, também conhecido como um "poema em prosa", é composto 33 (trinta e três) pequenas partes ou capítulos, contendo diversas palavras indígenas, algumas delas, inclusive, são hoje nome de municípios do estado do Ceará. Em suma, é a lenda da história do Ceará.

Mas, afinal, o que é uma lenda? De acordo com o Dicionário Online de Português, a palavra lenda expressa, hoje, múltiplos sentidos. Neste estudo, porém, a lenda é tratada como "uma História maravilhosa, fantástica ou mirabolante cujos personagens são seres sobrenaturais, geralmente contam tradições populares, folclóricas". Para o Dicionário Michaelis, lenda é compreendida como: "1. Relato oral ou escrito de acontecimentos, reais ou fictícios, aos quais a imaginação popular acrescenta uma boa dose de novos elementos; 2. Narrativa fantasiosa ou crendice do imaginário popular sobre seres encantados ou maravilhosos da natureza".

Se a narrativa de Iracema, lendariamente, retrata a origem da história do Ceará, em Macunaíma as muitas lendas se entrelaçam, dando vida à obra. Composta por 17 (dezessete) capítulos e o prólogo, já é possível identificar as aproximações entre os dois romances logo no capítulo inicial, pois a partir de óticas diferentes, ambos narram o nascimento da heroína/do herói e o contexto em que estão inseridos, assunto que retomarei adiante. Vale destacar que Alencar, ao dividir o livro em partes não insere título nas mesmas. Mário de Andrade, por sua vez, apresenta os títulos: Macunaíma; Maioridade; Ci, Mãe do Mato; Boiúna Luna; Piaimã; A Francesa e o Gigante; Macumba; Vei, a Sol; Carta pras Icamiabas; Pauí-Pódole; A velha Ceiuci; Tequeteque, Chupinzão e a injustiça dos homens; A piolhenta do Jiguê; Muiraquitã; A Pacuera de Oibê; Uraricoera; Ursa Maior e Epílogo. A cada capítulo o leitor vai se aventurando com as andanças e as mudanças macunaímicas. 
Quanto ao herói, acentuo, porém, que ao mesmo tempo em que Macunaíma é apresentado como "sem nenhum caráter", ele apresenta múltiplas faces, incorporando as várias faces do povo brasileiro (Fig. 2). Mas, por outro lado, esta expressão "sem nenhum caráter" vem questionar o caráter das pessoas frente ao "jeitinho brasileiro", que, macunaimicamente, procura se dar bem a qualquer custo.

Conforme já destaquei, a intenção é que, para além da análise, este texto da obra aponte caminhos acerca da literatura, colocando-a em diálogo com outros gêneros textuais, com outras linguagens. Pensando assim, explorei (02) duas imagens de cada obra, por acreditar na importância do "uso das imagens na educação"(MALTA, 2013). Segundo ele, "As imagens fazem parte do cotidiano das pessoas, sendo portanto, mais fácil de assimilar e recordar elementos que foram ensinados com o auxílio desse recurso, assim, como, no campo da academia, ressignificar aspectos históricos a partir do uso de fontes alternativas (Idem, p. 101).

Figura 3 - Ilustrações de Iracema

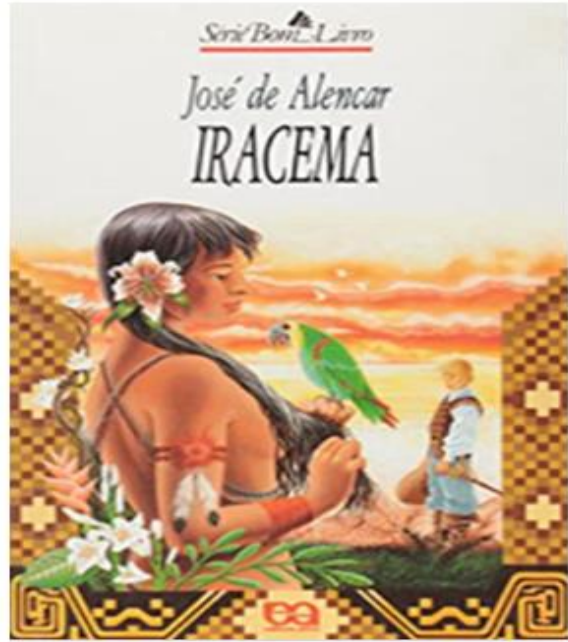

(A)

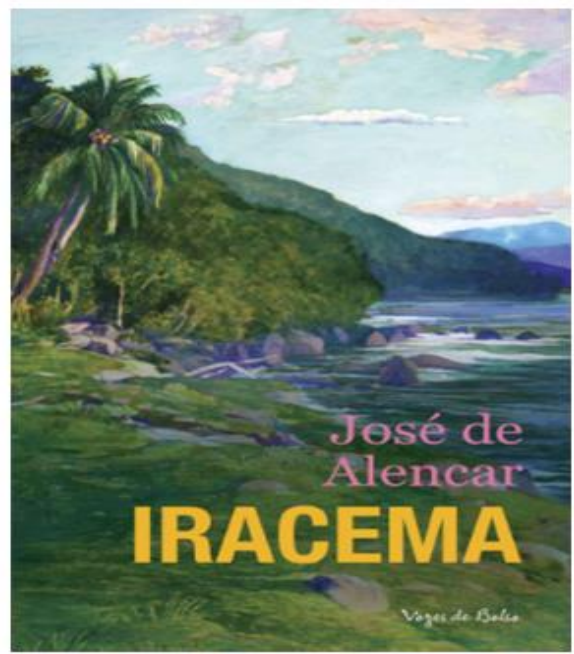

(B)

Legenda:(A) Ilustração Marcus de Sant'Anna; (B) Ilustração de capa: John La Farge.

Fonte: Ática, 1997; Vozes, 2016.

A figura em destaque traz as ilustrações de duas capas do romance alencarino. $\mathrm{O}$ tratamento da índia Iracema (A) e da natureza (B) remete ao nacionalismo exacerbado dos românticos, idealizado, nos transportando aos primeiros encontros entre os nativos e o colonizador: uma terra ainda não explorada. Além disso, demonstra a relação harmônica entre o índio e a natureza, o que não acontece no romance marioandradiano. 
Assim como em Iracema, busquei entre as várias ilustrações de capa do livro estudado aquelas que mais se relacionam com esta escrita. Na figura 4, tanto uma (A) quanto a outra (B) traduz a célebre frase repetida pelo herói: “ai! que preguiça!” Isso significa dizer que a representação do índio é de um índio oportunista e preguiçoso, corrompido pelos valores sociais de seu tempo.

Figura 4 - Ilustrações de Macunaíma

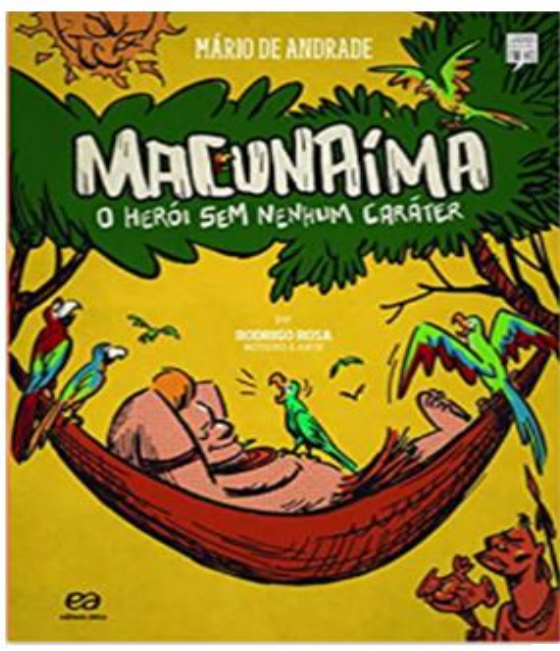

(A)

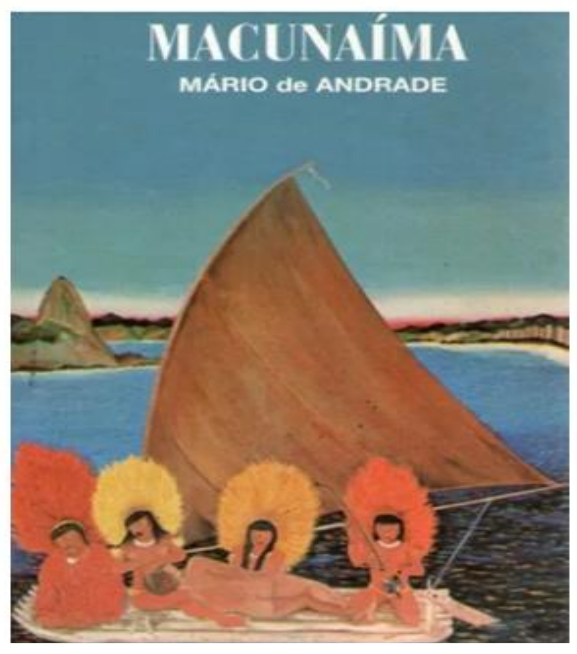

(B)

Legenda: (A) Ilustração de Rodrigo Rosa; (B) Desenho de capa, Rita Loureiro. Fonte: Ática, 2019; Garnier, 2001.

Servindo-me das figuras 3 e 4, destaco que enquanto Alencar alegoriza o processo de colonização do Brasil pelos colonizadores portugueses, Mário retrata o índio deixando a sua cidade em direção à cidade grande, a fim de encontrar o muiraquitã roubado. Esse anseio pela cidade, em alguns momentos se assemelha à ambição, ao sonho de se dar bem na vida, fruto da sociedade capitalista. Um exemplo disso pode ser destacado na afirmação: "meu filho, cresce depressa pra você ir pra São Paulo ganhar dinheiro (ANDRADE, 2001, p. 28). Com base nesta frase, afirma-se que o índio está corrompido pelos hábitos e desejos do homem branco, dito civilizado, prova disso é que na sua viagem para São Paulo, pois ao tomar banho nas "Pegadas de Sumé", ele, que era negro, logo fica branco. Ainda nesta afirmação, nota-se um comportamento capitalista, colocando os valores materiais, o dinheiro, em primeiro lugar, mesmo que isso custe a negação da sua própria cultura.

No que se refere à relação entre os heróis e a natureza, os trechos abaixo nos ajudarão a melhor compreendê-la: 
Além, muito além daquela serra, que ainda azula no horizonte, nasceu Iracema. Iracema, a virgem dos lábios de mel, que tinha os cabelos mais negros que a asa da graúna, e mais longo que seu talhe de palmeira (ALENCAR, 1997, p. 16).

No fundo do mato-virgem nasceu Macunaíma, herói da nossa gente. Era preto retinto e filho do medo da noite. Houve um momento em que o silêncio foi tão grande e o murmurejo do Uraricoera, que a índia tapanhumas pariu uma criança feia (ANDRADE, 2001, p. 13).

A partir do olhar para o início das duas obras, nota-se que ambas tratam do nascimento do índio, mas a partir de perspectivas diferentes. De um lado, Iracema, cujas características remetem a fauna e a flora brasileira. Do outro, mesmo nascendo no mato-virgem, isso não significa dizer que o herói interage com o mesmo. Acentuo que assim como no início, o final das duas obras também se assemelha: "Tudo passa sobre a terra" (ALENCAR, 1997, p. 82) e “Tem mais não" (ANDRADE, 2001, p. 162). Apesar dos diferentes enfoques, de um empregar a norma culta e outro uma linguagem popular, ambos retratam a figura do índio que, na disputa de forças, acaba perecendo, tanto na colonização como na "modernização" do Brasil. Viver na Paulicéia Desvairada ${ }^{v i}$ é um desafio constante.

A respeito da narrativa, o enredoem Iracema é a própria lenda contada pelo narrador. Sua ênfase está no relacionamento amoroso da índia com o guerreiro branco, o que a torna lenta, sentimentalista, presa a detalhes e subjetiva, representativa do "português escrito". Em Macunaíma, por sua vez, a narrativa é rápida e marcada por vários episódios fantásticos (mitos, lendas, causos populares) que se tecem no decorrer da narrativa.

\footnotetext{
A tribo se acabara, a família virara sombras, a maloca ruíra minada pelas saúvas e Macunaíma subira pro céu, porém ficara o aruaí do séquito daqueles tempos dantes em que o herói fora o grande Macunaíma imperador. E só o papagaio no silêncio do Uraricoera preservava do esquecimento os casos e a fala desaparecida. Só o papagaio conservava no silencia as frases e feitos do herói (ANDRADE, 2001, p. 162).
}

Chamo atenção para duas figuras que são marcantes nos dois romances: a jandaia Ará, em Iracema, e o papagaio, em Macunaíma. Com características muito próximas, as aves assumem o papel fundamental: lembrar o nome (Iracema), o nome e os fatos que marcaram a vida do seu amigo (Macunaíma). No final, a Ará já não repete mais o doce nome de Iracema e o papagaio conta "as frases e feitos do herói" e, em seguida, voa para Lisboa. Neste caso, Mário de Andrade vem lembrar a importância da oralidade, da contação de histórias, para que a tradição popular não morra, isto é, não entre no esquecimento. 
Sobre esta questão da preservação da sua cultura, os heróis são predestinados a cumprirem uma missão: Iracema, guardar o segredo da jurema; Macunaíma, guardar o muiraquitã. Todavia, as relações por eles tecidas (o contato com o colonizador e com a civilização, respectivamente) acabam afastando-os de suas raízes culturais. A partir disso, eles passam por vários dissabores, vivem a solidão, sentem-se cansados e acabam morrendo. Ao morrer, Iracema deixa Moacir, “o primeiro cearense, ainda no berço [...] Havia aí a predestinação de uma raça?” (ALENCAR, 1997, p. 81). A índia foi enterrada ao pé do coqueiro que o guerreiro branco amava. "E foi assim que um dia veio a chamar-se Ceará o rio onde crescia o coqueiro e os campos onde serpeja o rio" (Idem, p. 80, grifo meu). E Macunaíma? Solitário, cansado de viver terra subiu para o céu, onde foi transformado ${ }^{\mathrm{vii}}$ na constelação da “Ursa Maior”. “A Ursa Maior é Macunaíma. É mesmo o herói capenga que de tanto penar na terra sem saúde e com muita saúva, se aborreceu de tudo, foi-se embora e banza solitário no campo vasto do céu" (ANDRADE, 2001, p. 159).

A respeito das relações, da interação social, um dos traços do poema em prosa alencarino é a presença do homem branco, civilizado, adepto da religião católica, com domínio da língua local, entre os índios Tabajaras. Na rapsódia marioandradiana, o processo se inverte, pois retrata o índio que deixa a sua terra, sendo devorado pela civilização que se ancora no capital, na exploração da força de trabalho, resultando em formas diversas de exclusão: pela língua, pela falta de dinheiro, pela desvalorização dos seus saberes e da sua cultura. Apesar das astúcias de Macunaíma, o nativo se apresenta em condição de inferioridade ante a sociedade civilizada, que tem suas raízes na colonização, reafirmadas pelo capital.

Sacrifício, submissão, isolamento, miscigenação, são algumas características da relação colonizador/colonizado, nativo/civilizado. Moacir, apesar de ser "o primeiro cearense", conforme sugere Alencar, tem traços do sangue europeu. A partir disso, ouso inferir que Moacir e Macunaíma são parentes distantes, visto que, de diferentes formas, remetem à miscigenação que resulta dos processos de colonização. Enfim, para evitar "chovenão-molha" (ANDRADE, 2001, p. 83), vou ficando por aqui, compreendendo os limites deste texto. Além disso, não quero contrariar o nosso herói, que certamente leria este texto dizendo: “ai! que preguiça!” (Idem, p. 20).

\section{Para agora, "tem mais não"!}


Considerando este estudo uma viagem literária, chego ao seu final com o desejo de retomá-lo, de revisitá-lo, de buscar tecer outros diálogos. É um texto marcado pela revisitação, pelo reencontro com estes autores 18 anos após término da graduação em Letras. Que lição eu posso tirar de tudo isso? De lá para cá o campo também foi ampliado. Outros diálogos surgiram e cá estou com um novo mapa. Ele me desafia! Mas para agora, "tem mais não", apenas inquietações e umas poucas considerações.

A primeira consideração que faço diz respeito ao fato de que o Brasil, graças à sua pluralidade cultural, necessita problematizar/rever o que passou a se chamar de Literatura Brasileira, compreendendo que as literaturas populares (cordel, indígena e africana), marginalizadas historicamente, também são partes da mesma. Assim, com a indignação dos modernistas de 1922, acredito que é tempo de reafirmarmos a luta por uma pluralidade literária e por diferentes formas de nos narrarmos.

Pautado nas duas narrativas, a segunda consideração é que há elementos "míticolendários" tanto em Iracema como Macunaíma. Tais elementos remetem às marcas da oralidade, tão recorrentes da literatura popular (cordel). Contudo, convém dizer que Mário de Andrade (2001, p. 83) vai além de Alencar, ao destacar que nas andanças o herói se aperfeiçoa "nas duas línguas da terra, o brasileiro falado e o português escrito". Para além da crítica marioandradiana, característica da I geração modernista, até que ponto estas "duas línguas" ainda interferem na educação brasileira? De que maneira esta oralidade vem sendo trabalhada? Como os currículos de Língua Portuguesa vêm sendo pensados?

Voltando-me para as "imagens", para o uso de "quadrinhos", a terceira consideração que aqui faço reitera a importância de "maior utilização das imagens em sala de aula para potencializar a explicação de conteúdos pedagógicos", contribuindo, assim, para "um aprendizado de maneira mais lúdica e prazerosa" (MALTA, 2013, p. 131). Tornar a leitura mais prazerosa, reinventar a literatura, explorar "palavra, imagem e tecnologias digitais" (RIBEIRO, 2018), a oralidade, são caminhos possíveis. Partindo da premissa que "Tudo passa sobre a terra" (ALENCAR, 1997, p. 82): o Romance de Folhetim (Séc. XIX), as revistas e os manifestos (Séc. XX), apresento a seguinte indagação: e no século XXI, quais os desafios e as possibilidades para o trabalho com literatura?

A última consideração que faço, parte de uma reflexão macunaímica encontrada num trecho da sua "Carta pras Icamiabas" (ANDRADE, 2001, p. 79). Disse ele:

Porém, senhoras minhas! Inda tanto nos sobra, por este grandioso país [...]

Tudo vai num descalabro sem comedimento, estamos corroídos pelo morbo 
e pelos miriápodes! Em breve seremos novamente uma colônia da Inglaterra ou da América do Norte!... Por isso e para a eterna lembrança destes paulistas, que são a única gente útil do país, e por isso chamados de Locomotivas, nos demos ao trabalho de metrificarmos um dístico, em que se encerram os segredos de tanta desgraça:

\section{“POUCA SAÚDE E MUITA SAÚVA, OS MALES DO BRASIL SÃO”.}

"Por este grandioso país, inda um tanto nos sobra". As "sobras" me levam a pensar nas marcas da colonização: o que restou diante de tanta exploração? Muitas tribos pereceram, não resistiram, a exemplo de Iracema e Macunaíma. Viraram lendas! Mas esta pergunta é bem pertinente para o tempo presente: o que nos sobrou? E o que sobrará do que nos sobrou? As marcas da colonização ainda nos afetam, ditam modelos, excluem, oprimem! Por tudo isso, contrariando os puristas, concluo reafirmando que a literatura tem seu caráter político e transgressor, inspirando novos combates!

\section{Referências}

ABU, Angelo; X, Dan. Macunaíma em quadrinhos. São Paulo: Peirópolis, 2016 (Clássicos em HQ).

ALENCAR, José. Iracema. São Paulo:Ática, 1997. - (Série Bom Livro).

ALENCAR, José. Iracema. 1. ed. Petrópolis: Vozes, 2016. - (Selo Vozes de Bolso Literatura).

ANDRADE, Mário. Macunaíma: o herói sem nenhum caráter. 32. ed. Belo Horizonte-Rio de Janeiro: Garnier, 2001.

ANDRADE, Mário. Macunaíma: o herói sem nenhum caráter. São Paulo: Ática, 2019.

ARANHA, Maria Lúcia de Arruda; MARTINS, Maria Helena Pires. Filosofando: Introdução à Filosofia. São Paulo: Ática, 2000.

BAKHTIN, M. (Volochinov). Marxismo e Filosofia da Linguagem, São Paulo, Ed. HUCITEC, 1988.

BANDEIRA, Manuel. Poética. UFRGS, 2017. Disponível em: https://www.ufrgs.br/enunciarcotidianos/2017/04/11/poetica-manuel-bandeira/. Acesso em: 20 dez. 2021.

BOSI, Alfredo. Dialética da Colonização. São Paulo: Companhia das Letras, 1992.

BOSI, Alfredo. História Concisa da Literatura Brasileira. 39. ed. São Paulo: Cultrix, 2001. 
DICIO. Dicionário Online de Português. Lenda. Disponível em: https://www.dicio.com.br/lenda/ Acesso: 15 dez. 2021.

GONÇALVES, Isnard Alves. Iracema: um olhar inquiridor. 2002. Especialização em Literatura Brasileira - Universidade Regional do Cariri, URCA, 2002.

MALTA, Márcio José Melo. Uma imagem vale mais: o uso das imagens na educação como elemento potencializador. Conhecimento \& Diversidade, Niterói, n. 9, p. 130-139, jan./jun. 2013

MICHAELIS. Dicionário Brasileiro da Língua Portuguesa. Lenda. Disponível em: https://michaelis.uol.com.br/moderno-portugues/busca/portugues-brasileiro/lenda/ Acesso em: 15 dez. 2021.

MOISÉS, Massaud. História da Literatura Brasileira. São Paulo: Cultrix, 2001. Vol. III.

OBERG, Sílvia. Macunaíma, com M de Mário. In: ABU, Angelo; X, Dan. Macunaíma em quadrinhos. São Paulo: Peirópolis, 2016 (Clássicos em HQ), folha de rosto.

OLIVEIRA, Carlos César de. A importância do "ato" de ler em Paulo Freire e Bakhtin. In:Seminário Processos Formativos e Desigualdades Sociais (5: 2021: Rio de Janeiro) Trabalhos apresentados. Niterói: Intertexto, 2021. p. 356-363.

OLIVEIRA, Carlos César de. O indianismo e o lendário em Iracema de José de Alencar e Macunaíma de Mário de Andrade. 2004. 38 p. Monografia. Licenciatura em Letras Universidade Regional do Cariri, URCA, 2004.

RAMOS, Bruna Sola; SCHAPPER, Ilka. O encontro do leitor com a palavra alheia: leituras bakhtinianas. Revista Teias. v. 10, n.19 (2009), p. 1-7.

RIBEIRO, Ana Elisa. Escrever, hoje: palavra, imagem e tecnologias digitais na educação. - 1. ed. - São Paulo: Parábola, 2018.

SAMUEL, Rogel. Novo manual de teoria literária. Petrópolis-RJ: Vozes, 2002.

SANTIAGO, Silviano. O entre-lugar do discurso latino-americano. In: SANTIAGO, Silviano. Uma literatura nos trópicos: Ensaios sobre dependência cultural. 2. ed. Rio de Janeiro: Rocco, 2000, p. 9-26.

TÉRCIO, Jason. Em busca da alma brasileira: biografia de Mário de Andrade. Rio de Janeiro: Estação Brasil, 2019.

\footnotetext{
iDe acordo com Telê Porto Ancona Lopez "Nas lendas de heróis taulipang e arecuná, apresentada por KochGrünberg, Mário de Andrade encontrou o herói Macunaíma" (2001, p. 168). Acrescenta que "Mário de Andrade nunca escondeu que se inspirou na obra Vom Roraima zum Orinoco - Do Roraima ao Orenoco - do etnógrafo naturalista alemão Theodor Koch-Grünberg, publicado em cinco volumes entre 1916 e 1924" (Ibidem, grifos da autora). Por fim, com base no etnógrafo alemão, Lopez (Ibidem) afirma que "o nome do herói tribal parece conter como parte essencial a palavra MAKU, que significa "mau"e o sufixo IMA, "grande". Assim, Macunaíma significaria "O Grande Mau", um nome, segundo observa Grünberg, "que calha perfeitamente com o caráter intrigante e funesto do herói” (Ibidem, grifos da autora).
} 
ïEm 2004, finalizei a Graduação em Letras na Universidade Regional do Cariri - URCA, quando, então, produzi a monografia que serviu como base para este texto, sob a orientação da Prof. ${ }^{a}$ Mestra Maria Socorro de Morais Martins, a quem explicito a minha gratidão e dedico este trabalho. Ressalto que à época eu já atuava como professor de Literatura em escolas de ensino médio e pré-vestibulares populares. Acrescento, porém, que a monografia foi organizada em: Introdução; 1. O índio nas concepções romântico e modernista; 2. Iracema e Macunaíma nas trilhas do mítico-lendário; 2.1 Iracema: a lenda da fundação do Ceará; 2.2 Macunaíma, uma representação lendário do homem brasileiro; 3. A relação dialógica entre Iracema e Macunaíma, seguindo-se das considerações finais. Porém, para este estudo, inspirei-me apenas nos capítulos 1 e 3, tendo em vista a amplitude da temática.

iiiQuinhentismo (Literatura de Informação e Literatura de Catequese); Seiscentismo ou Barroco, Setecentismo, Arcadismo ou Neoclassicismo. Estas são formas como os estilos/períodos/correntes literárias são apresentados nos manuais de literatura.

iv Aproveito este movimento de escrita para rememorar os tempos de estudante secundarista na Escola de Ensino Médio Gov. Adauto Bezerra (1999), em Juazeiro do Norte-CE, e para expressar gratidão à minha então professora de Literatura Maria Ferreira dos Santos, que me instigou a mariandradiar a partir de Macunaíma, tema que retomei na graduação.

v'Segundo Bakhtin (1988, p. 29), “Toda imagem artístico-simbólica ocasionada por um objeto físico particular já é um produto ideológico. Converte-se, assim, em signo o objeto físico, o qual, sem deixar de fazer parte da realidade material, passa a refletir e a refratar, numa certa medida, uma outra realidade".

viObra de Mário de Andrade, lançada em 1922.

vii“‘ntão Pauí-Pódole teve dó de Macunaíma. Fez uma feitiçaria. Agarrou três pauzinhos jogou pro alto e virou Macunaíma com todo o estenderete dele, galo galinha gaiola revólver relógio, numa constelação nova. É a constelação da Ursa Maior"(ANDRADE, 2001, p. 159). 